\title{
Job burnout, self-efficacy theory and job satisfaction in a sample of greek bank clerks
}

\author{
Eleftheria Mantelou*, Maria-Christina Tzioti, Nick E Degleris, Andreas Solias, Manto Karamberi \\ From $1^{\text {st }}$ International Congress on Neurobiology and Clinical Psychopharmacology \\ and European Psychiatric Association Conference on Treatment Guidance \\ Thessaloniki, Greece. 19-22 November 2009
}

\section{Background}

The aim of this study is the exploration of the job burnout syndrome in Greek bank clerks as well as the examination of the demographic factors that seem to have an impact on it. Based on Maslach and Jackson's [1] theory, the job burnout syndrome has three components: emotional exhaustion, depersonalization and reduced professional efficacy within the workplace. In addition, we examined the correlation between job burnout and two other concepts, self-efficacy as described by Albert Bandura [2] and job satisfaction. Finally, we sought to examine whether the three components of the job burnout syndrome differentiate in relation to some demographic characteristics of the sample (i.e., age, educational level, working experience, gender and personal contact with customers).

\section{Materials and methods}

The following questionnaires were used: The Greek version of the general self-efficacy scale of Shwarzer, the Maslach Burnout Inventory - General Survey (MBI-GS), the Oldenburg Burnout Inventory (OLBI), the Job Satisfaction Questionnaire and a demographic characteristics questionnaire.

\section{Results}

The relationship between job burnout and self-efficacy was not found to be statistically significant, whereas job satisfaction was correlated with some MBI and OLBI dimensions.

\section{Conclusions}

All demographic factors, except for gender, were correlated to job burnout dimensions. Last but not least, it would be interesting to study the relationship between

Psychotherapeutic Center of Piraeus, Greece self-efficacy and job burnout in other professional groups as well.

Published: 22 April 2010

\section{References}

1. Maslach C, Jackson SE: Maslach Burnout Inventory. Manual. Palo Alto, CA: Consulting Psychologists Press, 21986.

2. Bandura A: Self- efficacy: Toward a unifying theory of behavioral change. Psychological Review 1977, 84:191-215.

3. Demerouti E, Bakker AB, Nachreiner F, Schaufeli WB: 'The job demandsresources model of burnout'. Journal of Applied Psychology 2001, 86:499-512.

4. Schwarzer R: Measurement of perceived self-efficacy. Psychometric scales for cross-cultural research Berlin, Germany: Freie Univesität Berlin 1993.

doi:10.1186/1744-859X-9-S1-S191

Cite this article as: Mantelou et al: Job burnout, self-efficacy theory and job satisfaction in a sample of greek bank clerks. Annals of General Psychiatry 2010 9(Suppl 1):S191.
Submit your next manuscript to BioMed Central and take full advantage of:

- Convenient online submission

- Thorough peer review

- No space constraints or color figure charges

- Immediate publication on acceptance

- Inclusion in PubMed, CAS, Scopus and Google Scholar

- Research which is freely available for redistribution

Submit your manuscript at www.biomedcentral.com/submit
C Biomed Central 